2. Cakuletion Title

Cafculation: Precipitation Characteristics for Storm Water Management

3. Document Identfier (including Revision Number)

CAL-WHS-MM-000001, Rẹv 01

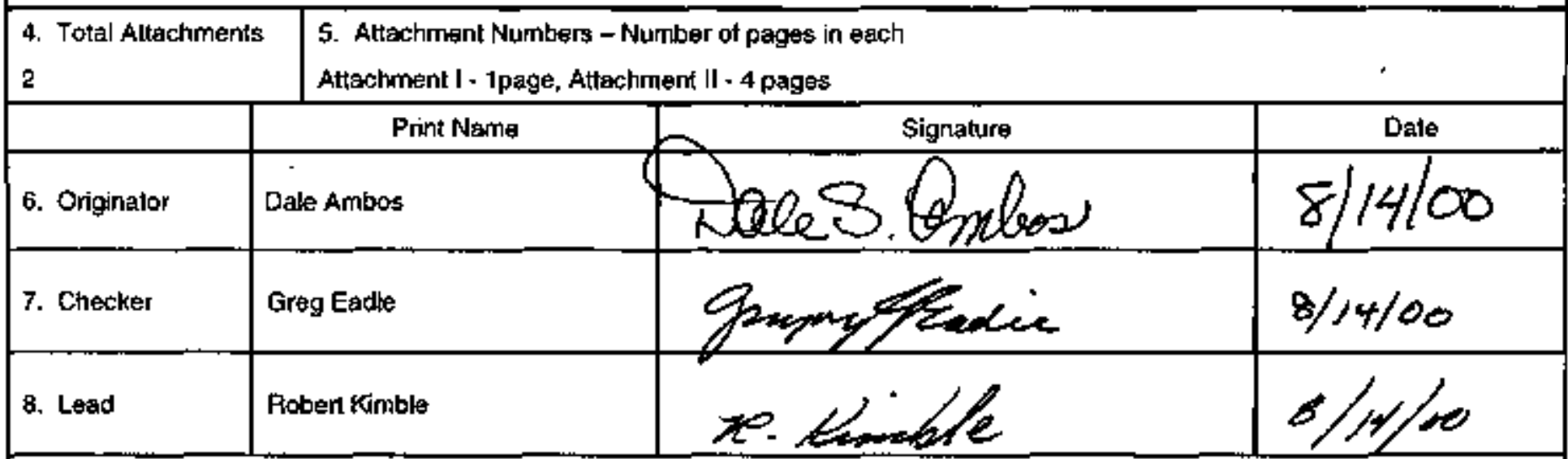

9. Rẹmarks

\title{
Revigion History
}

10. Fevision No.

00

01
11. Description of Revision

Initial tssue

Fevision is required to more fully juslify the use ol the calculation method which is based on NOAA Hydrometecrological Report 49 (Hansen 1964) as applied by Bullard (1992) to the Nevada Test Site. This justication is presented as an assumption. Corrected misalknments between the list of relerences in the Calculation and the DIRS isting. Corrected one DIRS reforence with an incorrect qualty doftinition. Added to the Purpose section the revision of AP-3.12Q (Rev 0/ACN 2) undenwhich the Calculation was prepared. 


\section{CONTENTS}

\section{Page}

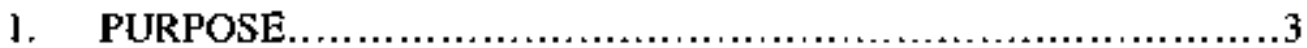

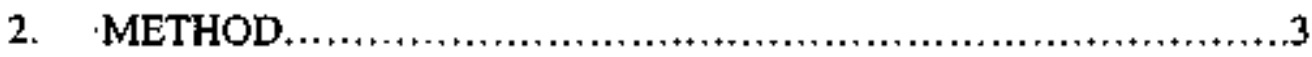

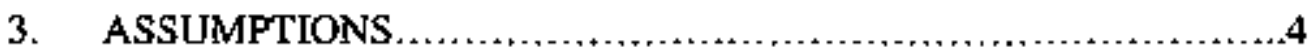

| 4. USE OF COMPUTER SOFTWARE AND MODELS $\ldots \ldots \ldots \ldots \ldots \ldots . . \ldots$

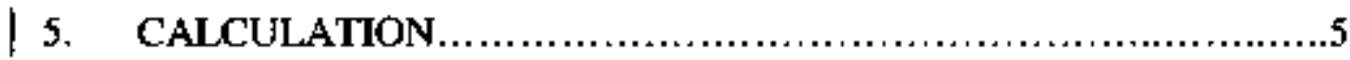

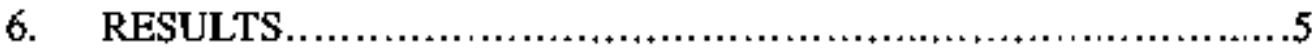

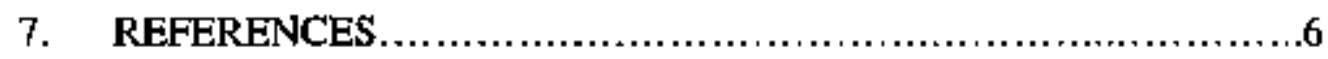

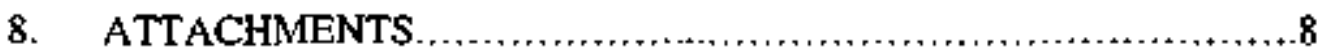

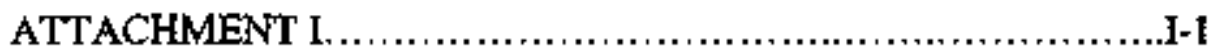

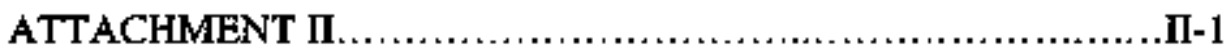


Title: Calculation: Precipitation Characteristics for Storm Water Management

\section{PURPOSE}

This Cafculation is intended to satisfy engineering requirements for maximum 60-minule precipitation amounts for 50 and 100-year return periods at and near Yucca Mountain. This data requirement is documented in the Interface Control Document for Support Operations to Surface Facilities Operations Functional and Organizational Interfaces (CRWMS M\&O 1998a). These developed data will supplement the information on 0.1 hour to 6-hour (in 0.1-hour increments) probable maximum precipitation (PMP) presented in the report, Precipitation Design Criteria for Storm Water Management (CRWMS M\&O 1998b). The Reference Information Base (RIB) item, Precipitation Characteristics for Storm Water Management (MO9902RIB00045.000), was developed based on CRWMS M\&O (1998b) and will be supplemented (via revision) with the information developed in this Calculation. The Development Plan for the Calculation: Precipitation Characteristics for Storm Water Management (CRWMS M\&O 2000) was prepared in accordance with AP-2.13Q, Technical Product Development Planning. This calculation was developed in accordance with AP-3.12Q, Rev. 0/RCN 2.

\section{METHOD}

The method for estimating probable maximum flood-producing precipitation amounts is presented in Hydrometeorological Report 49 (HMR 49) (Hansen et al 1984). For the purpose of determining PMP over a 1 square mile area, Hansen (1984) postulated that localized thunderstorms of 6-hour duration could produce extreme or PMP-type events. These thunderstomn events tend to be intense, of shorter duration than general storns. and are more likely to produce probable maximum flooding.

The methodology developed in HMR 49 involved developing PMP estimates using empirical data from a number of notable intense local storms which occurred in the southwest U.S. Most storms were of a duration of 1-3 hours; however, a duration limit of 6 hours was used to combine the results of two or more individual storms that produce iocal PMP conditions. Ratios of 6-hour and 1-hour (6/1-hour) precipitation totals from PMP events were developed for the southwest U.S. (Hansen 1984, Figure 4.7, page 118).

Bullard (1992) applied the method specifically to the Nevada Test Site (NTS) to determine the PMP in this region of the western U.S. Bullard determined that the 6/1hour ratio for the NTS to be 1.35 based on the information presented in Hansen (1984). That is,

Extreme 6-hout precipitation amount $=1.35$

\section{Extreme 1-hour amount from same storm}

Another way to express this relationship is that, for a 6-hour storm total, most of the precipitation (74 percent) falls during one hour and the remaining amount (26 percent) falls during the remaining five hours. Usually, the heaviest precipitation amount occurs 
during the first one to two hours of the storm and diminishes during the storm's remaining life cycle.

| This methodology was also used in CRWMS M $\& O$ (1998b) to determine incremental rainfall amounts from 0.1 to 6 hours (in 0.1-hour increments) based on a 6-hour PMP event of 5 total inches near Yucca Mountain. A 24-hour total amount of 5 inches (storm with a 6-hour duration) was determined to be realistically conservative for the Yucca Mountain region (CRWMS M\&O 1997). Randerson (1997) corroborated this PMP value (5 inches in 24-hours) for the southern Nevada Test Site (NTS) in an independent study based on historical NTS precipitation data collected by the National Oceanic and Atmospheric Administration (NOAA) Air Resources Laboratory Special Operations Research Division (ARL/SORD). Again, the 24-hous total can be considered to have occurred within six contiguous hours because of the natuse of intense thunderstorm events. Randerson (1997) also calculated a 5-inch 24-hour total to have a return period of 500 years.

This ratio (1.35) is applied in this Calculation to relate 50 and 100-year 24-hour total amounts resulting from 6-bour PMP events to 50 and 100-year 1-hour amounts. The development plan did not require special controls for source data or control of the electronic management of source data. Data were not processed electronically, therefore, AP-SV.1Q, Control of the Electronic Management of Data, does not apply. Calculations were performed by hand calculator throughout.

\section{ASSUMPTIONS}

3.1 Storm event duration and reporting. Customarily, precipitation amounts are reported as 24-hour totals for a given location. However, the storm event that produced the daily total may have had a much shorter duration. This is especially true for measurements resulting from localized summertime thunderstorm activity with much shorter durations than the general synoptic-scale wintertime storm. This is the situation in the desert southwest. Extrerne accumulations usually occur from intense, isolated thunderstorms with durations of six hours or less. Such heavy storms of shorter duration can produce the most significant local flooding (Bullard 1992). Crow (1989) reported that southern Nevada flash flood-producing summer storms usually had durations of three hours or less.

Therefore, the assumption is made thal extreme 24-hour precipitation totals, which are used as source data (CWRMS M\&O 1997), represent extreme PMP events that began and ended within a period of six hours or less. This assumption, applied throughout this Calculation, is necessary so that the method mentioned above can be employed. This assumption does not require confirmation.

3.2. Methodology. The methodology developed in (Hansen et al. 1984) and applied by Bullard (1992) to the NTS is assumed to be valid for the intended purposes as stated in these references. It is also assumed that no further verification is needed for the 
Title: Calculation: Precipitation Characteristics for Storm Water Management

methodology since it was developed under the auspices of the National Oceanic and Atmospheric Administration (NOAA) for general use by the public and was based on data collected and verified by NOAA.

\section{USE OF COMPUTER SOFTWARE AND MODELS}

There are no computer programs, software routines, or models used. The Calculation was performed using a hand calculator.

\section{CALCULATION}

The source data for this calculation is presented in Attachment $I$ which is modified after CRWMS M\&O (1997), Table 4-3, Estimated and Observed Maximurn Daily Precipitation. This table presents 24-hour 50 and 100-year precipitation extremes from a number of Jocations at Yucca Mountain and the surrounding region. This Calculation is based on the most conservative (highest) 50 and 100 -year return 24-hour amounts estimated for the general surrounding region with the potential for occurring at Yucca Mountajn.

The values selected are from the Cane Springs precipitation record and are 3.10 inches and $\mathbf{3 . 5 2}$ inches for $\$ 0$ and 100 -year returns, respectively. Cane Springs is located on the NTS, approximately 33 kilometers east of Yucca Mountain. The Cane Springs precipitation site is part of the meteorological network operated by NOAA ARL/SORD. Applying the assumption that 24-hour amounts resulting from localized PMP storms can be considered 6 -hour totals and applying the ratio defined in equation ( 1 ), the following results are obtained.

For the 50-year return amount:

$$
\begin{aligned}
& \frac{3.10 \text { inches (6-hour extreme) }}{X \text { inches ( } \mathrm{d} \text {-hour extreme) }}=1.35 \\
& X=2.30 \text { inches (50-year, }[\text {-hour amount) }
\end{aligned}
$$

Similarly, for the 100 -year seturn amount:

$$
\begin{aligned}
& \frac{3.52 \text { inches (6-hour extreme) }}{X \text { inches (1-hour extreme) }}=1.35 \\
& X=2.61 \text { inches (100-year, 1-hour amount) }
\end{aligned}
$$

For the purpose of this Calculation, the 1-hour totals are equivalent to 60-minute totals as required by CRWMS M\&O (1998a).

\section{RESULTS}


The results of calculations (2) and (3) are presented in Table $L$. The 50 and 500-year return 60-minute PMP amounts were calculated in response to the data needs as specified in CRWMS M\&O (1998a). The Cane Springs 50 and I00-year return amounts (CRWMS-M\&O 1997, Table 4-3) are used because they are the most conservative data from the Yucca Mountain region. The Cane Springs data, along with the other historic NTS precipitation data (GSO00200001221.002) have been designated "Accepted" in accordance with AP-SHI.2Q, Qualification of Unqualified Data and the Documentation of Rationale for Accepted Data and are designated "N/A - Accepted Data (AMOPE Approved)." No further confirmation is needed prior to use in accordance with AP3. 15Q, Management of Technical Product Inputs, Attachment 4. The results of this Calculation shall not be compared to design criteria and requirements, nor shalt conclusions be used for recommendations for design development or program disection.

Table 1. Calculated naximum 60-minute precipitation amounts for 50 and 100-year return periods.

\begin{tabular}{|c|c|c|c|c|}
\hline \multirow{2}{*}{ Location } & \multicolumn{2}{|c|}{ 50-Year Returns (inches) } & \multicolumn{2}{|c|}{ 100-Year Returns (inches) } \\
\hline & 24-Hour* & 60-Minute & 24-Hour* & 60-Minute \\
\hline $\begin{array}{c}\text { Yucca Mountain } \\
\text { Region (Southem } \\
\text { NTS) }\end{array}$ & 3.10 & 2.30 & 3.52 & 2.61 \\
\hline $\begin{array}{l}\text { * (CRWMS M\&O } \\
\text { hours. }\end{array}$ & 7 , Table 4 & Based on a lo & ed storm w & uration of 6 \\
\hline
\end{tabular}

\section{REFERENCES}

\subsection{PROCEDURES}

AP-2.13Q, Technical Product Development Planning. Washinglon, D.C.: U.S. Department of Energy, Office of Civilian Radioactive Waste Management. ACC: MOL.20000620.00067.

AP-3.12Q, Calculations. Washington, D.C.: U.S. Department of Energy, Office of Civiljan Radioactive Waste Management. ACC: MOL.20000620.0068

AP-3.15Q, Managing Technical Product Inputs. Washington, D.C.: U.S. Department of Energy, Office of Civilian Radioactive Waste Management. ACC: MOL.20000218.0069.

AP-SIII.2Q, Qualffication of Unqualified Data and the Documentation of Rationale for Accepted Data. Washington, D.C.: U.S. Department of Energy, Office of Civilian Radjoactive Waste Management. ACC: MOL.20000203.0629. 
Title: Calculation: Precipitation Characteristics for Storm Water Maragement

Dncument Identiffer: CAL-WHS-MM-00000L, Rev 01

AP-SV.1Q, Control of the Electronic Management of Data. Washington, D.C.: U.S. Department of Energy, Office of Civilian Radioactive Waste Management. ACC: MOL.20000512,0068.

\subsection{PUBLICATIONS}

Bullard, K.L. 1992. Nevada Test Site Probable Maximum Flood Study Part of U.S. Geological Survey Flood Potential and Debris Hazard Study Yucca Mountain Site. Denver, Colorado: U.S. Department of the Interior, Bureau of Reclamation. TKC: 205030.

Crow, L. W. 1989. Analysis of Pertinent Weather Factors Related to the Frequency and Magnitude of Rain Storms Capable of Producing Flash Floods in Clark County and Particularly in the Vicinity of Las Vegas, Nevada. LWC\#318. Denver, Colorado: Loren W. Crow Consultants. TIC: 233197.

CRWMS M\&O 1997. Engineering Design Climatology and Regional Meteorological Conditions Report. B00000000-01717-5707-00066, Rev. 00. Las Vegas, Nevada: CRWMS M\&O. DTN: MO98I IDEDCRMCR.000. ACC: MOL.19980304.0028.

CRWMS M\&O 1998a. Interface Control Document for Support Operations to Surface Facilities Operations Functional and Organizational Interfaces. B00000000-01717. 8100-00018, Rev, 00. Las Vegas, Nevađa: CRWMS M\&O. ACC: MOL 19981116.0439.

CRWMS M\&O 1998b. Precipitation Design Criteria for Storm Water Management. B00000000-01717-1704-00001, Rev. 00. Las Vegas, Nevada: CRWMS M\&O. DTN: MO9811STORMWTR.000. ACC: MOL.19990216.0207.

CRWMS M\&O 2000. Development Plan for the Calculation: Precipitation Characteristics for Storm Water Management. Development Plan TDP-WHS-MM000001, Rev. 00. Las Vegas, Nevada. CRWMS M\&O. ACC: MOL.20000530.0248.

Hansen, E.M.; Scbwarz, F.K.; and Riedel, J.T. 1984. Probable Maximum Precipitation Estimates, Colorado River and Great Basin Drainages. National Weather Service Hydrometeorological Report-No. 49. Silver Springs, Maryland: National Oceanic and Atmospheric Administration. TTC: 220224.

Randerson, D. 1997. Analysis of Extreme Precipitation Events in Southem Nevada. NOAA Technical Memorandum ERL ARL-221. Silver Spring, Maryland: U. S. Department of Commerce, National Oceanic and Atmospheric Administration. TIC: 233167. 
Title: Calculation: Precipitation Characteristics for Storm Water Management

\subsection{DATA}

GS000200001221,002. Precipitation Data for Nevada Test Site, 1957-1994, from Air Resources Laboratory, from National Oceanographic and Atmospheric Administration (NOAA) Precipitation Data. Submittal date: $2 / 29 / 2000$.

MO9902RIB00045,000. Precipitation Characteristics for Storm Water Management.

| Reference Information Base item. Submitta! date: 02/24/1999.

GS000100001221.001. Earthinfo, Inc. Westem US Meteorologic Station Weather Data NCDC Summary of the Day (West 1) and NCDC Summary of the Day (West 2).

| Submittal date: 01/25/2000.

See Attachment II for the reference list of meteorological data collected at Yucca Mountain.

\subsection{ATTACHMENTS}

Attachment I. Modifjed from CRWMS M\&O (1997) Table 4-3, Estinated and Observed Maximum Daily Precipitation

Attachment II. Meteorological Data Collected at Yucca Mountain - 1986 through 1997 
Environmental, Safety \& Health Calculation

Title: Calculation: Precipitation Characteristics for Storm Water Management

Document Identifier: CAL-WHS-MM-000001, Rev O1

\section{ATTACHMENT I}

Modified from CRWMS M\&O (1997), Table 4-3. Estimated and Observed Maximum Daily Precipitation

\begin{tabular}{|c|c|c|c|c|}
\hline \multicolumn{5}{|c|}{ Summary of Daily Precipitation Projections (Inches) } \\
\hline Location & $\begin{array}{l}\text { 50-year } \\
\text { Return }\end{array}$ & $\begin{array}{l}\text { 100-year } \\
\text { Return. }\end{array}$ & $\begin{array}{l}\text { Largest recorded } \\
\text { yalue }\end{array}$ & Period of Record \\
\hline Site ${ }^{\circ}$ & 2.68 & 3.03 & 1.39 & $1986-1996$ \\
\hline Site $2^{\mathrm{a}}$ & 2.59 & $2.9 \pm$ & 1.65 & $1990-1996$ \\
\hline Site $3^{2}$ & [.9] & 2.14 & 1.33 & $1990-1996$ \\
\hline Site $4^{x}$ & 2.61 & 2.92 & 1.72 & $90 \& 192-96$ \\
\hline Site $5^{2}$ & 2.05 & 2.30 & 1,63 & $1990-1996$ \\
\hline Site $6^{2}$ & 2.43 & 2.73 & 1.40 & $1993-1996$ \\
\hline Site $7^{\text {a }}$ & 2.38 & 2.65 & $1.2 \mathrm{i}$ & $1993-1996$ \\
\hline Site $8^{2}$ & 2.14 & 2.41 & 1.18 & $1993-1996$ \\
\hline Site $9^{a}$ & 1.60 & 1.79 & 0.90 & $1993-1996$ \\
\hline 4JA-all data & 2.78 & 3.23 & 3.22 & $1957-1996$ \\
\hline $4 J \mathrm{~A}-10 \mathrm{yrs}^{\mathrm{b}}$ & 2.92 & 3.33 & 2.04 & $1987-1996$ \\
\hline Desert Rock b & 2.69 & 3.09 & 3.52 & $10 / 63-6 / 96$ \\
\hline Mencury ${ }^{b}$ & 2.77 & 3.19 & 3.63 & $12 / 68-12 / 93$ \\
\hline Rock Valley & 2.84 & 3.24 & 2.98 & $2 / 63-12 / 93$ \\
\hline Cane Springs ${ }^{b}$ & 3.10 & $\mathbf{3 . 5 2}$ & 3.47 & $9 / 64-12 / 93$ \\
\hline Amargosa Farms ${ }^{c}$ & 2.36 & 2.74 & 2.00 & $1965-1996$ \\
\hline Am Farms-10 yrs ${ }^{c}$ & 2.07 & 2.34 & 1.45 & $1987-1996$ \\
\hline Beatty ${ }^{\circ}$ & 1.96 & 2.21 & 1.65 & $1948-1972$ \\
\hline Beatty $8 \mathrm{~N}^{\mathrm{C}}$ & 2.32 & 2.64 & 1.90 & $1972-1996$ \\
\hline Beatty $8 \mathrm{~N}-10$ yrs ${ }^{\circ}$ & 2.41 & 2.75 & 1.25 & $1987-1996$ \\
\hline Las Vegas & 2,13 & 2.43 & 2.58 & $1949-1992$ \\
\hline
\end{tabular}

NOTES: $\quad a=$ Source data collected by the YMP. DTNs: (See Atch II)

$b=$ Source data acquired from NOAA ARL/SORD at the NTS.

DTN: G\$000200001221,002.

$\mathrm{c}=$ Source data acquired from NOAA. DTN: GS000100001221.001 
Title: Calculation: Precipitation Characteristics for Storm Water Managenent

Document Identifier: CAL-WHS-MM-00000], Rev 01

\section{ATTACHMENT II}

\section{Meteorological Data Collected at Yucca Mountain 1986 through 1997}

M09903VALMM931.000. Validated Meteorological Monitoring Data, January - June 1993. Submittal date: 03/29/1999.

MO9903VALMM932.000. Validated Meteorological Monitoring Data, July - September [993. Submittal date: 03/29/1999.

MO9903VALMM933.000. Validated Meteorological Monitoring Data, October December 1993. Submittal date: 03/29/1999.

M09903VALMM961.000. Validated Meteorological Monitoring Data, January - March 1996. Submittal date: 03/29/1999.

MO9903VALMM962.000. Validated Meteorological Monitoring Data, April - June 1996. Submittal date: 03/29/1999.

MO9903VALMM963.000. Validated Meteorological Monitoring Data, July - September 1996. Submittal date: 03/29/1999.

MO9903VALMM964.000. Validated Meteorological Monitoring Data, October December 1996. Submittal date: 03/29/1999.

M09905VAMMDD85.000. Validated Meteorological Monitoring Data, December 1985. Submittal date: $05 / 12 / 1999$.

MO9905VMMDAJ86.000. Validated Meteorological Moritoring Data, April - June 1986. Submittal date: $05 / 13 / 1999$.

M09905VMMDAJ87.000. Validated Meteorological Monitoring Data, April - June 1987. Submittal date: $05 / 18 / 1999$.

M09905VMMDAJ88.000. Validated Meteorological Monitoring Data, April - June 1988. Submittal date: $05 / 18 / 1999$.

MO9905VMMDA.189.000. Validated Meteorological Monitoring Data, April - June 1989. Submittal date: 05/20/1999. 
Title: Calculation: Precipitation Characteristics for Storm Water Management

I Document Identifjer: CAL-WHS-MM-000001,Rev 01

\section{ATTACHMENT II (cont)}

\section{Meteorological Data Collected at Yucca Mountain 1986 through 1997}

MO990SVMMDAJ90.000. Validated Meteorological Monitoring Data, April - June 1990. Submittal date: 05/21/1999.

MO9905VMMDAJ91 000. Validated Meteorological Monitoring Data, April - June 1991. Submittal date: 05/21/1999.

MO9905VMMDAJ92.000. Validated Meteorological Monitoring Data, April - June [992. Submittal date: 05/24/1999.

MO9905VMMDAJ94.000. Validated Meteorological Monitoring Data, April - June 1994. Submittal date: 05/29/1999.

MO9905VMMDJM86.000. Validated Meteorological Monitoring Data, January - March 1986. Submittal date: 05/13/1999.

MO9905VMMDJM87.000. Validated Meteorological Monitoring Data, January - March 1987. Submittal date: 05/13/1999.

MO9905VMMDIM88.000. Validated Meteorological Monitoring Data, January - March 1988. Submittal date: $05 / 18 / 1999$.

M09905VMMDSM89.000. Validated Meteorological Monitoring Data, January - March 1989. Submittal date: $05 / 20 / 1999$.

MO9905VMMDJM90.000. Validated Meteorological Monitoring Data, January - March 1990. Submittal date: 05/21/1999.

MO9905VMMDJM91.000. Validated Meteorological Monitoring Data, January - March 1991. Submittal date: 05/21/1999.

MO9905VMMDIM92.000. Validated Meteorological Monitoring Data, January - March 1992. Submittal date: 05/24/1999.

MO9905VMMDJM94.000. Validated Meteorological Monitoring Data, January - March 1994. Submittal date: $05 / 29 / 1999$.

MO9905VMMDJS86.000. Validated Meteorological Monitoring Data, July - September 1986. Submittal date: 05/13/1999. 
Title: Calculation: Precipitation Characteristics for Storm Water Management

Document Identifier: CAL-WHS-MM-000001.Rev OI

\section{ATTACHMENT II (cont)}

Meteorological Data Collected at Yucca Mountain 1986 through 1997

MO9905VMMDJ\$87.000. Validated Meteorological Monitoring Data, July - September 1987. Submittal date: 05/18/1999.

MO9905VMMDIS88.000. Validated Meteorological Monitoring Data, Juty - September 1988. Submittal date: $05 / 18 / 1999$.

MO9905VMMDJS89.000. Validated Meteorological Monitoring Data, July - September 1989. Submittal date: $05 / 20 / 1999$.

MO9905VMMDJS 90,000 . Validated Meteorological Monitoring Data, July - September 1990. Submittal date: 05/21/1999.

MO9905VMMDJS91,000. Validated Meteorological Monitoring Data, July - September 199l. Submittal date: 05/21/1999.

MO9905VMMDJS92.000. Validated Meteorological Monitoring Data, July - September 1992. Submittal date: 05/24/1999.

MO9905VMMDJ\$94,000. Validated Meteorological Monitoring Data, July - September 1994. Submittal date: 05/29/1999.

MO9905VMMDOD86,000, Validated Meteorological Monitoring Data, October December 1986. Submittal date: 05/13/1999.

MO9905VMMDOD87.000. Validated Meteorological Monitoring Data, October December 1987. Submittal date: 05/18/1999.

MO9905VMMDOD88.000. Valjdated MeteorologicaI Monitoring Data, October December 1988. Submittal date: 05/20/1999.

MO9905VMMDOD89.000. Validated Meteorological Monitoring Data, October December 1989. Submittal date: 05/20/1999.

M09905VMMDOD90,000. Validated Meteorological Monitoring Data, October December 1990. Submittal date: 05/21/1999.

MO9905VMMDOD91.000. Validated Meteorological Monitoring Data, October December 1991. Submittal date: 05/21/1999. 
Title: Calculation: Ptecipitation Characteristics for Storm Water Management Document Identifier: CAL-WHS-MM-000001, Rev 01

\section{ATTACHMENT II (cont)}

\section{Meteorologlcal Data Collected at Yucca Mountain 1986 through 1997}

MO9905VMMDOD92.000. Validated Meteorological Monitoring Data, October December 1992. Submittal date: 05/24/1999.

MO9905VMMDOD94.000. Validated Meteorological Monitoring Data, October December 1994. Submittal date: 05/29/1999.

TMO0000000001.100. Validated Meteorological Data, January - March 1997. Submittal date: 04/18/1997.

TM00000000001.104. Validated Meteorological Data, April - June 1997. Submittal date: $07 / 21 / 1997$.

TMO0000000001.107. Validated Meteorological Data, July - September 1997.

Submittal date: 10/22/1997.

MO98METDATA1 10000. Validated Meteorological Data, October - December, 1997.

Submittal date: 01/29/1998 